\title{
Sensitivity Analysis of Snow Load Distribution to Single-Layer Cylindrical Shell Structures
}

\author{
Junlin Wang $^{1 *}$, Hua Guo ${ }^{1}$, Tengfei Ma², Shuli Zhao ${ }^{1}$ and Jianheng Sun ${ }^{1}$ \\ ${ }^{1}$ College of Urban and Rural Construction, Agricultural University of Hebei, Baoding 071001, China \\ ${ }^{2}$ Department of Architectural Engineering, North China Institute of Aerospace Engineering, Langfang 065000, China \\ *Corresponding author
}

\begin{abstract}
The large - span single - layer reticulated shell structure is a structure sensitive to the load distribution. Different distribution of snow load has an effect on the stable bearing capacity of the reticulated shell structure. The unfavorable snow load distribution may cause the stable bearing capacity of the reticulated shell to decrease greatly. In this paper, a single oblique rod type reticulated shell structure is taken as an example. According to the characteristics of the reticulated shells, eight stripes are divided into a lattice size in the longitudinal direction and span direction, and the snow load distribution is classified according to the permutation and combination. The stability of the reticulated shell structure is determined by the arc-length method, taking into account the sensitivity of the snow load in the longitudinal direction and the span direction. The results show that the maximum sensitivity coefficient of the stability of the reticulated shells with snow loads is 0.083 and 0.404 , respectively, along the longitudinal length and the span direction. Compared with the sensitivity coefficient of the snow load distribution position along the longitudinal length direction and the span direction, the most sensitive snow load distribution position of the reticulated shell structure is obtained from the 4th to 8th rows.
\end{abstract}

Keywords-cylindrical reticulated shells; snow load; stable bearing capacity; partition combination; sensitivity

\section{INTRODUCTION}

The space reticulated shell structure is an efficient structure in bearing capacity and transmission force, depending on its form. It is widely used in traditional areas such as commercial buildings, traffic buildings and sports buildings, and has a bright future in emerging areas such as industrial buildings and agricultural buildings. The unfavorable snow load distribution may cause the stable bearing capacity of the reticulated shell structure to decrease sharply and suddenly collapse[1-3], and the accident caused by the snow-induced collapse of the singlelayer reticulated shell structure has caused serious loss of life and property. Such as 1963 in Romanian Bucharest, a singlelayer spherical reticulated shell with $93.5 \mathrm{~m}$ span collapse overall in the local snow load[4]. 1978 United States, Connecticut Hartford City Gymnasium also collapsed in heavy snow[5]. 1997 Liaoning Anshan City, China, the snow loads across half-span of five arched roofs of a feed company caused a large area collapse[6]. 2005 Shandong Weihai, a roof of steel plant structure overload and collapse due to snow load sudden increase[6]. Therefore, it is very important to study the antisnow disaster design of reticulated shell structure deeply.

\section{RETICUlated SHELl StABILITy ANALYSis METHOD}

\section{A. Calculation Models}

The member bars of reticulated shells are modeled by Beam188 in the ANSYS software. The roof load and the structural weight are transformed into the concentrated load on the nodes of the reticulated shell structure according corresponding to the mass. The snow load applied to each node of the reticulated shell structure can be described as

$$
F_{\mathrm{i}}(x, y, z)=S_{\mathrm{k}, \mathrm{i}}(x, y, z) A_{\mathrm{i}}
$$

where, $F_{\mathrm{i}}$ is the equivalent load force of the snow load at the node $i$; $A_{\mathrm{i}}$ is the equivalent snow load area at the node $i$; $S_{\mathrm{k}, \mathrm{i}}$ is the standard value of the snow pressure at the node $i$, as follow:

$$
S_{\mathrm{k}, \mathrm{i}}(x, y, z)=\mu_{\mathrm{r}, \mathrm{i}} S_{0}
$$

where, is the roof snow distribution coefficient at the node , calculated on the basis of norms; is the basic snow pressure of the place where the reticulated shells are located, found from the norms.

Model parameters: The monoclinic type single layer cylindrical reticulated shell structure shown in Figure1 has a length $L$ of $20 \mathrm{~m}$, width B of $15 \mathrm{~m}$, vector height $\mathrm{f}$ of $5 \mathrm{~m}$. Threeway fixation is used as a constraint in the longitudinal direction.

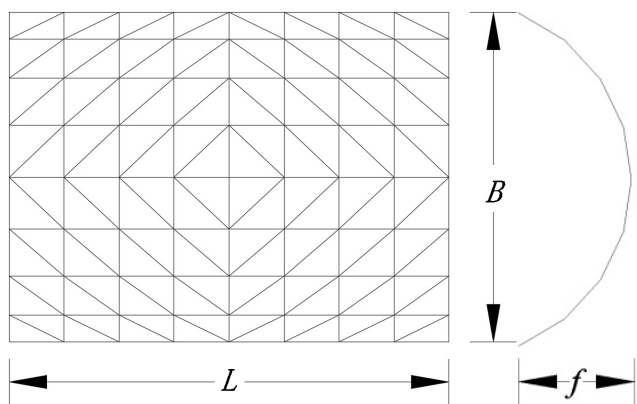

FIGURE I. SCHEMATIC DIAGRAM OF THE SINGLE-LAYER CYLINDRICAL RETICULATED SHELL

Seamless steel pipes with cross-section size $\Phi 83 \mathrm{~mm} \times 4.5 \mathrm{~mm}$ are used for member bars. Material parameters: Steel model is 
Q345, material density $\rho$ is7.85 $\times 10^{3} \mathrm{~kg} / \mathrm{m}^{3}$, yield strength $\mathrm{f}_{\mathrm{y}}$ is $345 \mathrm{~N} / \mathrm{mm}^{2}$, Young's modulus E is $2.1 \times 105 \mathrm{~N} / \mathrm{mm}^{2}$, transverse deformation coefficient $v$ is 0.26 . Analysis parameters: The ideal elastic-plastic model, the Mises yield criterion and the bilinear isotropic model are used.

\section{B. Zoning Programs}

In this paper, taking the single oblique rod reticulated shell structure as an example the distribution scheme of snow load is determined by using the combined zoning method. The details are as follows:

(1) A grid is divided into eight columns in the longitudinal direction as shown in figure 2. The distribution of snow load is determined by permutations and combinations and represented by an 8-dimensional sequence number of "12345678". When the value of a dimension is 0 , the snow load is not arranged in the column.

(2) In the span direction a grid is divided into 8 rows of stripes (shown in Figure 3). The same as above, the distribution of snow load is determined by permutations and combinations and represented by an 8-dimensional sequence number of "12345678". When the value of a dimension is 0 , the snow load is not arranged in the column.

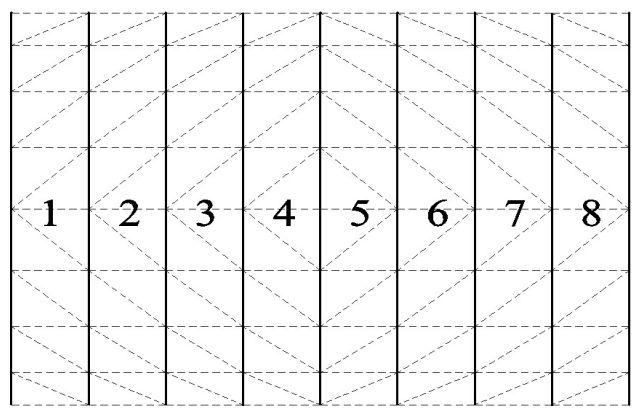

FIGURE II. SNOW LOAD PARTITION ALONG LONGITUDINAL LENGTH

\begin{tabular}{|l|l|l|l|l|l|l|}
\hline & & & 1 & & & \\
\hline & & & 2 & & & \\
\hline & & 3 & & & \\
\hline & & & 4 & & & \\
\hline & & & 5 & & & \\
\hline & & & 6 & & & \\
\hline & & 7 & & & \\
\hline
\end{tabular}

FIGURE III. SNOW LOAD PARTITION ALONG SPAN DIRECTION

\section{Tracking Balance Path of the Structure}

Arc length method is used for nonlinear solution. In the analysis process, assuming that the load is independent of the deformation and is proportionally loaded in the structure, the equilibrium equation of the incremental form at any time is:

$$
{ }^{t} K \Delta U^{(i)}={ }^{t+\Delta t} \lambda^{(i)} R-{ }^{t+\Delta t} F^{i-1}
$$

where, ${ }^{t} K$ is the tangent stiffness matrix of the structure at time $t, \Delta U^{(i)}$ is the iteration increment of the current displacement, ${ }^{t+\Delta t} \lambda$ is the load proportional coefficient at time,${ }^{t+\Delta t} F$ is the internal force vector of the bar node at time $t+\Delta t, R$ is the load distribution vector.

If the square sum of $\lambda$ and $U$ is used as a variable, the generalized form of the arc length constraint equation is:

$$
\alpha\left\{\left({ }^{t+\Delta t} \lambda^{i+1}-\Delta \lambda^{(i)}\right)+\Delta \lambda^{(i)}\right\}^{2}+U^{(i) \mathrm{T}} U^{(i)}=(\Delta l)^{2}
$$

where, $\Delta l$ is the arc length increment of each iteration; $\alpha$ is the scale factor. When $\alpha=1$, the equation is the spherical arc length method.

\section{SENSITIVITY ANALYSIS OF SNOW LOAD DISTRIBUTION POSITIONS}

The influence of different positions of snow load distribution on the stable bearing capacity of reticulated shells is reflected by the sensitivity coefficient. The sensitivity coefficient is calculated as follows[9]:

$$
S_{\mathrm{F}, \mathrm{i}}=\frac{F_{0}-F_{\mathrm{i}}}{F_{0}}
$$

where, $F_{\mathrm{i}}$ and $F_{0}$ are the stable bearing capacity of the reticulated shell structure under the snow load distribution scheme $i$ and the full-span distribution scheme. $S_{\mathrm{F}, \mathrm{i}}$ is the sensitivity coefficient of the snow load distribution scheme $i$, that the smaller the numerical value is, the smaller the influence of the snow load distribution on the stability of the reticulated shell structure.

\section{A. Sensitivity Coefficient of Snow Load Distribution Position along the Longitudinal Length Direction}

In order to study the sensitivity of the snow load distribution position along the longitudinal length direction to the stable bearing capacity of the reticulated shell structure, a grid is divided into 8 columns in the longitudinal direction, and the snow load distribution position is determined according to the permutation and combination. The stability of the reticulated shell structure is determined by arc-length method, and the sensitivity in different positions along longitudinal direction is investigated. The sensitivity coefficient of the stability of the reticulated shell structure to the different distribution positions of the snow load is shown in Table 1 . The maximum coefficient of sensitivity of the reticulated shell structure is 0.083 when snow load is arranged in only the 1th column bar area, which means that this snow load distribution in the longitudinal span direction has the greatest effect on the stable bearing capacity of the reticulated shell structure. 
TABLE I. SENSITIVITY COEFFICIENT OF SNOW LOAD DISTRIBUTION POSITION ALONG LONGITUDINAL LENGTH DIRECTION

\begin{tabular}{|c|c|c|c|c|c|c|c|}
\hline $\begin{array}{c}\text { Snow load distribution } \\
\text { location }\end{array}$ & $\begin{array}{l}\text { Sensitivity } \\
\text { coefficient }\end{array}$ & $\begin{array}{c}\text { Snow load } \\
\text { distribution } \\
\text { location } \\
\end{array}$ & $\begin{array}{l}\text { Sensitivity } \\
\text { coefficient }\end{array}$ & $\begin{array}{c}\text { Snow load } \\
\text { distribution } \\
\text { location } \\
\end{array}$ & $\begin{array}{l}\text { Sensitivity } \\
\text { coefficient }\end{array}$ & $\begin{array}{c}\text { Snow load } \\
\text { distribution } \\
\text { location } \\
\end{array}$ & $\begin{array}{l}\text { Sensitivity } \\
\text { coefficient }\end{array}$ \\
\hline 10000000 & -1.715 & 10040008 & -1.208 & 10305070 & -0.585 & 10345608 & -0.183 \\
\hline 02000000 & -2.697 & 10005600 & -1.088 & 10305008 & -0.670 & 12005678 & -0.086 \\
\hline 00300000 & -3.683 & 10005070 & -1.258 & 10300670 & -0.688 & 12040678 & -0.150 \\
\hline 00040000 & -4.236 & 10000670 & -1.191 & 10300608 & -0.757 & 12045078 & -0.198 \\
\hline 12000000 & -0.621 & 02340000 & -0.634 & 10045600 & -0.583 & 12300678 & -0.188 \\
\hline 10300000 & -0.868 & 02305000 & -0.786 & 10045070 & -0.698 & 00045678 & 0.007 \\
\hline 10040000 & -1.095 & 02300600 & -0.935 & 10045008 & -0.742 & 00305678 & -0.050 \\
\hline 10005000 & -1.316 & 02300070 & -1.054 & 10040670 & -0.755 & 00340678 & -0.092 \\
\hline 10000600 & -1.523 & 02045000 & -0.937 & 10005670 & -0.634 & 00345078 & -0.154 \\
\hline 10000070 & -1.756 & 02040600 & -1.134 & 10000678 & -0.286 & 00345608 & -0.228 \\
\hline 10000008 & -2.151 & 02040070 & -1.302 & 02345000 & -0.395 & 00345670 & -0.265 \\
\hline 02300000 & -1.143 & 02005600 & -1.225 & 02340600 & -0.479 & 02005678 & -0.073 \\
\hline 02040000 & -1.464 & 00345000 & -0.945 & 02340070 & -0.548 & 02040678 & -0.133 \\
\hline 02005000 & -1.763 & 00340600 & -1.131 & 02305600 & -0.574 & 02045078 & -0.202 \\
\hline 02000600 & -2.115 & 12340000 & -0.084 & 02305070 & -0.672 & 02045608 & -0.283 \\
\hline 02000070 & -2.474 & 12305000 & -0.149 & 02300670 & -0.723 & 02045670 & -0.320 \\
\hline 00340000 & -1.636 & 12300600 & -0.203 & 02045600 & -0.643 & 02300678 & -0.185 \\
\hline 00305000 & -2.036 & 12300070 & -0.247 & 02045070 & -0.729 & 02305078 & -0.268 \\
\hline 00300600 & -2.344 & 12300008 & -0.286 & 00345600 & -0.567 & 02305608 & -0.347 \\
\hline 00045000 & -1.820 & 12045000 & -0.226 & 02345678 & 0.083 & 02305670 & -0.368 \\
\hline 12300000 & -0.249 & 12040600 & -0.289 & 10345678 & 0.055 & 02340078 & -0.326 \\
\hline 12040000 & -0.363 & 12040070 & -0.341 & 12045678 & 0.018 & 02340608 & -0.413 \\
\hline 12005000 & -0.436 & 12040008 & -0.388 & 12305678 & -0.019 & 02345008 & -0.362 \\
\hline 12000600 & -0.532 & 12005600 & -0.377 & 00345678 & 0.056 & 10005678 & -0.105 \\
\hline 12000070 & -0.611 & 12005070 & -0.437 & 02045678 & 0.023 & 10040678 & -0.169 \\
\hline 12000008 & -0.683 & 12005008 & -0.497 & 02305678 & -0.019 & 10045078 & -0.244 \\
\hline 10340000 & -0.499 & 12000670 & -0.516 & 02340678 & -0.067 & 10045608 & -0.329 \\
\hline 10305000 & -0.631 & 12000608 & -0.586 & 02345078 & -0.116 & 10300678 & -0.226 \\
\hline 10300600 & -0.750 & 12000078 & -0.704 & 02345608 & -0.158 & 10305078 & -0.313 \\
\hline 10300070 & -0.856 & 10345000 & -0.328 & 02345670 & -0.148 & 10305608 & -0.417 \\
\hline 10300008 & -0.948 & 10340600 & -0.409 & 10045678 & -0.005 & 10340078 & -0.398 \\
\hline 10045000 & -0.766 & 10340070 & -0.470 & 10305678 & -0.050 & 12000678 & -0.273 \\
\hline 10040600 & -0.920 & 10340008 & -0.530 & 10340678 & -0.103 & 12005078 & -0.387 \\
\hline 10040070 & -1.059 & 10305600 & -0.494 & 10345078 & -0.161 & 12345678 & - \\
\hline
\end{tabular}

B. Sensitivity Coefficient of Snow Load Distribution Position along the Span Direction

Similarly, in order to study the sensitivity of the snow load distribution position along the span direction to the stable bearing capacity of the reticulated shell structure, a grid is divided into 8 columns in the span direction, and the snow load distribution position is determined according to the permutation and combination. The stability of the reticulated shell structure is determined by arc-length method, and the sensitivity in different positions along span direction is investigated. The sensitivity coefficient of the stability of the reticulated shell structure to the different position of the snow load is shown in Table 2. The maximum coefficient of sensitivity of the reticulated shell structure is 0.404 when the snow load is arranged in the stripe area of the 4th to 8th rows, which means that this snow load distribution in the span direction has the greatest influence on the stable bearing capacity of the reticulated shell structure. 
TABLE II. SENSITIVITY COEFFICIENT OF SNOW LOAD DISTRIBUTION POSITION ALONG SPAN DIRECTION

\begin{tabular}{|c|c|c|c|c|c|c|c|}
\hline $\begin{array}{c}\text { Snow load distribution } \\
\text { location }\end{array}$ & $\begin{array}{l}\text { Sensitivity } \\
\text { coefficient }\end{array}$ & $\begin{array}{c}\text { Snow load } \\
\text { distribution } \\
\text { location } \\
\end{array}$ & $\begin{array}{l}\text { Sensitivity } \\
\text { coefficient }\end{array}$ & $\begin{array}{c}\text { Snow load } \\
\text { distribution } \\
\text { location } \\
\end{array}$ & $\begin{array}{l}\text { Sensitivity } \\
\text { coefficient }\end{array}$ & $\begin{array}{c}\text { Snow load } \\
\text { distribution } \\
\text { location } \\
\end{array}$ & $\begin{array}{l}\text { Sensitivity } \\
\text { coefficient }\end{array}$ \\
\hline 10000000 & -10.450 & 10040008 & -0.448 & 10305070 & -0.797 & 10345608 & 0.184 \\
\hline 02000000 & -1.825 & 10005600 & 0.188 & 10305008 & -0.306 & 12005678 & 0.262 \\
\hline 00300000 & -0.476 & 10005070 & -0.164 & 10300670 & -0.459 & 12040678 & -0.256 \\
\hline 00040000 & -0.426 & 10000670 & -0.002 & 10300608 & -0.387 & 12045078 & -0.155 \\
\hline 12000000 & -1.315 & 02340000 & 0.339 & 10045600 & 0.294 & 12300678 & -1.369 \\
\hline 10300000 & -0.386 & 02305000 & 0.004 & 10045070 & 0.058 & 00045678 & 0.404 \\
\hline 10040000 & -0.398 & 02300600 & -0.413 & 10045008 & -0.048 & 00305678 & 0.213 \\
\hline 10005000 & -0.491 & 02300070 & -0.144 & 10040670 & -0.035 & 00340678 & -0.254 \\
\hline 10000600 & -0.524 & 02045000 & 0.076 & 10005670 & 0.328 & 00345078 & 0.175 \\
\hline 10000070 & -1.959 & 02040600 & -0.623 & 10000678 & 0.042 & 00345608 & 0.206 \\
\hline 10000008 & -12.927 & 02040070 & -0.435 & 02345000 & 0.392 & 00345670 & 0.287 \\
\hline 02300000 & 0.023 & 02005600 & 0.073 & 02340600 & 0.180 & 02005678 & 0.274 \\
\hline 02040000 & -0.126 & 00345000 & 0.308 & 02340070 & 0.253 & 02040678 & -0.203 \\
\hline 02005000 & -0.872 & 00340600 & -0.016 & 02305600 & -0.272 & 02045078 & -0.126 \\
\hline 02000600 & -0.885 & 12340000 & 0.362 & 02305070 & -0.270 & 02045608 & 0.211 \\
\hline 02000070 & -3.220 & 12305000 & 0.032 & 02300670 & -1.651 & 02045670 & 0.308 \\
\hline 00340000 & 0.200 & 12300600 & -0.306 & 02045600 & 0.199 & 02300678 & -0.815 \\
\hline 00305000 & -0.289 & 12300070 & -0.069 & 02045070 & -0.143 & 02305078 & -0.322 \\
\hline 00300600 & -2.620 & 12300008 & 0.042 & 00345600 & 0.210 & 02305608 & -0.293 \\
\hline 00045000 & -0.018 & 12045000 & 0.094 & 02345678 & 0.149 & 02305670 & 0.009 \\
\hline 12300000 & 0.069 & 12040600 & -0.554 & 10345678 & 0.274 & 02340078 & 0.236 \\
\hline 12040000 & -0.090 & 12040070 & -0.365 & 12045678 & 0.307 & 02340608 & 0.158 \\
\hline 12005000 & -0.917 & 12040008 & -0.116 & 12305678 & 0.021 & 02345008 & 0.379 \\
\hline 12000600 & -0.977 & 12005600 & 0.049 & 00345678 & 0.300 & 10005678 & 0.350 \\
\hline 12000070 & -2.022 & 12005070 & -0.487 & 02045678 & 0.320 & 10040678 & 0.019 \\
\hline 12000008 & -1.417 & 12005008 & -1.030 & 02305678 & 0.045 & 10045078 & 0.078 \\
\hline 10340000 & 0.216 & 12000670 & -0.160 & 02340678 & -0.030 & 10045608 & 0.304 \\
\hline 10305000 & -0.254 & 12000608 & -0.785 & 02345078 & 0.295 & 10300678 & -0.361 \\
\hline 10300600 & -1.634 & 12000078 & -2.247 & 02345608 & 0.260 & 10305078 & -0.710 \\
\hline 10300070 & -0.737 & 10345000 & 0.318 & 02345670 & 0.136 & 10305608 & -0.026 \\
\hline 10300008 & -0.430 & 10340600 & 0.010 & 10045678 & 0.390 & 10340078 & 0.070 \\
\hline 10045000 & -0.041 & 10340070 & 0.097 & 10305678 & 0.182 & 12000678 & -0.088 \\
\hline 10040600 & -0.363 & 10340008 & 0.204 & 10340678 & -0.370 & 12005078 & -0.429 \\
\hline 10040070 & -0.892 & 10305600 & -0.057 & 10345078 & 0.189 & 12345678 & - \\
\hline
\end{tabular}

\section{CONCLUSION}

(1) Based on the structure of the single oblique rod reticulated shell, the distribution scheme of snow load is determined by combining the characteristics of the reticulated shell and the combined zoning method. The sensitivity coefficient of stable bearing capacity of reticulated shell structures is obtained when the snow load distribution is distributed along the longitudinal length and span direction, and they were 0.083 and 0.404 , respectively. It can be seen that the sensitivity of the snow load distribution position along the span direction is significantly greater than that in the longitudinal direction.
(2) By comparing the sensitivity of the snow load distribution position along the longitudinal length direction and the span direction, the most sensitive snow load arrangement is the 4th to 8th rows, which is the most unfavorable arrangement of the snow load. It may result in a significant reduction in the stable bearing capacity of the reticulated shell structure. Therefore, it is necessary to consider the most unfavorable snow load arrangement to ensure the safety of the reticulated shell structure. In particular, it is necessary to consider the influence of the most unfavorable combination of wind load and snow load on the safety of the reticulated shell structure. 


\section{ACKNOWLEDGMENT}

This study was supported by Science and Technology Program of Ministry of Construction (2015-K2-028), Key Basic Research Projects of Science and Technology Department of Hebei Province(15965401D) and Education Youth Fund Project of Hebei Provincial Education Department (QN2015047).

\section{REFERENCES}

[1] S.S. Ross. "Construction disaster: design, failures causes, and prevention”. New York: McGraw-Hill Inc. pp. 299-322, 1984.

[2] Y.N. Zhang,Y.Q. Wang, and Y.J. Shi, "The analysis of cause and of snow storm disaster of large-span light steel structure". Journal of Shenyang Jianzhu University(Natural Science) , vol. 27 ,pp. 272-280, 2011.

[3] Y.Q. Wang, Z.W. Hu, Y.J. Shi, Y. Zhang, M. Liu, "Analysis and reflection on snow disaster accidents of Steel Structures of Light-weight buildings with portal frame”, China Civil Engineering Journal, vol. 42 ,pp. 65-70, 2009.

[4] S.L. Dong, W.D. Zhan, "Non-linear stability critical loads of singlelayer and double-layer reticulated spherical shallow shells based on continum analogy method”, ENGINEERING MECHANICS, vol. 21 , pp. 6-14, 2004.

[5] E.A. Smith, H.I. Epstein, "Hartford coliseum roof collapse: structural collapse sequence and lessons learned", Civil Engineering-ASCE, vol. 50, pp. 59-62, 1980.

[6] J.L. Wang, H.M. Li, X.Q. Ren, J.H. Sun. "Stability of single-layer latticed domes under asymmetrical and non-uniform snow loads", Spatial Structures, vol. 22, pp. 17-22, 2016.

[7] W.F. Du, B.Q. Gao, S.L. Dong, "Research on the most dangerous snow distribution on single-layer spherical latticed shells", ENGINEERING MECHANICS, vol. 31, pp. 83-87, 2014.

[8] Ministry of Housing and Urban-Rural Development of the People's Republic of China . Chinese architectural structure load standards (GB50019-2012). Beijing: China Construction Industry Press, 2012.

[9] P. C. Pandey, S. V. Barai. Structural sensitivity as a measure of redundancy [J]. Journal of Structural Engineering, vol. 123, pp. 360-364, 1997. 